\title{
Development of Solid Oxide Fuel Cell Based System in Stand Alone Mode
}

\author{
D. Vera* and F. Jurado*
}

Department of Electrical Engineering, University of Jaén, 23700 EPS Linares (Jaén), Spain

\begin{abstract}
Several technologies are being used in distributed generation applications with variable degree of success. Among those are: wind turbines, small-scale hydropower plants, biomass, microturbines, photovoltaic arrays and fuel cells. In a fuel cell, the chemical energy incorporated in the fuel is converted directly to electricity and heat. Fuel cell technology is one of the most interesting energy conversion systems offering nearly zero emissions, flexibility of operation and high conversion efficiency. Increasing demand for power and the depletion of fossil fuels are providing opportunities for the development of fuel cells as power generating systems. In this paper the modeling of Solid Oxide Fuel Cell (SOFC) based generation system, fuel processor (methane reformer) and power conditioning unit (inverter) are presented. Within acceptable limits, the effects of load variation on output voltage, efficiency and fuel flow demanded are investigated.

SOFC based generation system use a stack consisting of 384 fuel cells connected in series, this provides $120-140 \mathrm{~kW}$ output power in stand-alone mode. The system has been analyzed when a step load is applied.

Matlab-Simulink ${ }^{\circledR}$ is used for the modeling and simulation of the fuel processor, fuel cell generator and power conditioning unit.
\end{abstract}

Keywords: Distributed generation, fuel processor, fuel cell, control, power conditioning unit.

\section{INTRODUCTION}

Hydrogen can be produced from the thermochemical gasification of many biomass materials, such as municipal solid waste, agricultural or forest wastes or wood chips from short rotation forestry plantations. The synthesis gas coming from a gasifier will incorporate methane and carbon monoxide in addition to the hydrogen

Essentially, a fuel cell comprises of two porous electrodes separated by an ion-conducting electrolyte. The functioning principle of a SOFC is that hydrogen moves through the anode and reacts with oxygen. Throughout this reaction, water and heat are created, at the same time freeing electrons. The electrons go through an external circuit to the cathode, developing electrical power. In the cathode, oxygen moves through the electrode and the electrons are absorbed. Throughout this reaction, oxygen ions are constituted, which are carried through the electrolyte via empty spaces, ending the electric circuit. The chemical reactions that occur within the SOFC are as follows:

$$
\begin{array}{ll}
\mathrm{O}_{2}+2 \mathrm{e}^{-} \rightarrow 1 / 2 \mathrm{O}^{2-} & \text { Cathode reaction } \\
\mathrm{H}_{2}+\mathrm{O}^{2-} \rightarrow \mathrm{H}_{2} \mathrm{O}+2 \mathrm{e}^{-} & \text {Anode reaction } \\
\mathrm{H}_{2}+1 / 2 \mathrm{O}_{2} \rightarrow \mathrm{H}_{2} \mathrm{O} & \text { Overall reaction }
\end{array}
$$

As the name indicates, the SOFC possesses a ceramic electrolyte, commonly yttria-stabilised zirconia (YSZ), which is a substance that conducts oxygen ions at temperatures above $800{ }^{\circ} \mathrm{C},[1]$. Materials usually employed for the

*Address correspondence these authors at the Department of Electrical Engineering, University of Jaén, 23700 EPS Linares (Jaén), Spain; E-mails: dvera@ujaen.es; fjurado@ujaen.es anode and the cathode are nickel-YSZ-cermet and strontium doped lanthanum manganite, respectively. The interconnect links the anode of one cell to the cathode of the adjacent. The substance can be ceramic or metallic depending on the working temperature and fuel cell design. The cell is electrolyte-supported when working at about $1000{ }^{\circ} \mathrm{C}$ and electrode-supported when working at about $800{ }^{\circ} \mathrm{C}$.

Fuel cells can work on different fuels varying from hydrogen to gasified solid fuels, such as biomass. Fuels from renewable origins are of particular importance for the future, but nowadays the most recognized for fuel cells is natural gas. More information on fuel cell can be encountered in Blomen and Mugerwa [2] and Larminie et al. [1]. The output from the fuel cell is DC power. When the system generation provides power to a residential load, or to the electrical grid, a power conditioning unit is needed [3].

The positive properties of fuel cells for high efficiency power generation at any scale and of biomass as a renewable energy source which is not intermittent, location dependent or very unmanageable to store, indicate that a combined heat and power system consisting of a fuel cell integrated with a wood gasifier may provide a combination for delivering heat and electricity cleanly and efficiently.

\section{SYSTEM GENERATION MODEL}

\section{SOFC}

The electrochemical model of SOFC described in this paper is based on a model developed by Padulles et al. [4]. The assumptions for the fuel cell model are as follows:

- The gases are ideal.

- The fuel cell is fed with hydrogen and air. 
- The electrode channels are small enough that the pressure drop across them is negligible.

- The ratio of pressures between the inside and outside of the electrode channels is large enough to assume choked flow.

- The fuel cell temperature is stable.

- The Nernst equation applies.

- The losses are as follows: activation, concentration and ohmic.

The upper limit theoretic work is the change in Gibbs free energy of the cell reaction, and the matching reversible voltage is the electromotive force given by the Nernst equation:

$V_{0}=N_{0}\left(E_{0}+\frac{R T_{F C}}{n_{e} F}\left(\ln \frac{p_{\mathrm{H}_{2}} p_{\mathrm{O}_{2}}^{0,5}}{p_{\mathrm{H}_{2} \mathrm{O}}}\right)\right)$

Due to irreversibility in the cell performance, the cell voltage, $V_{F C}$, is invariably lower than the ideal voltage, $V_{0}$. This deviation is called polarization and is the summation of three losses: activation, concentration and ohmic polarization.

$\mathrm{V}_{\mathrm{FC}}=\mathrm{V}_{0}-\mathrm{V}_{\text {losses }}$
$V_{\text {losses }}=\Delta V_{\text {act }}+\Delta V_{\text {conc }}+\Delta V_{\text {ohm }}$

- Activation losses: The general expression that represents the activation losses for both electrodes comes expressed by Butler-Volmer equation, [5].

$$
\Delta V_{a c t}=\frac{2 R T_{F C}}{n_{e} F} \operatorname{senh}^{-1}\left(\frac{i}{2 i_{0 a}}\right)+\frac{2 R T_{F C}}{n_{e} F} \operatorname{senh}^{-1}\left(\frac{i}{2 i_{0 c}}\right)
$$

- Concentration losses: There exist expressions proposed by Chan to calculate the concentration losses, both for cathode and anode, [5], but in present paper, there has been adopted a more simplified empirical expression proposed by Hahn, [6], and that gives us a good approximation of those losses.

$\Delta V_{\text {conc }}=m_{c} e^{n i}$

- Ohmic polarization losses: In general, using the Ohm's law, these losses can be defined according to Eq. (14).

$\Delta V_{\text {ohm }}=r I_{F C}$

The efficiency of a fuel cell is calculated as the power divided by the LHV of the fuel (methane):

$$
\eta_{f c}=\frac{P_{F C}}{\dot{m}_{\text {fuel }} L H V_{\text {fuel }}}
$$

In this paper, the fuel cell model uses a constant average cell voltage and a constant average fuel utilization to calculate the production of the fuel cells according to Faraday's law, Eq. (10):

$$
P_{F C}=\left(\Sigma n_{e} y_{i}\right) U N_{a} F V_{F C}
$$

A Simulink model [7] was presented to simulate the fuel cell based on the analysis performed above (Fig. 1). The parameters used in the simulation are summarized in Table $\mathbf{1}$.

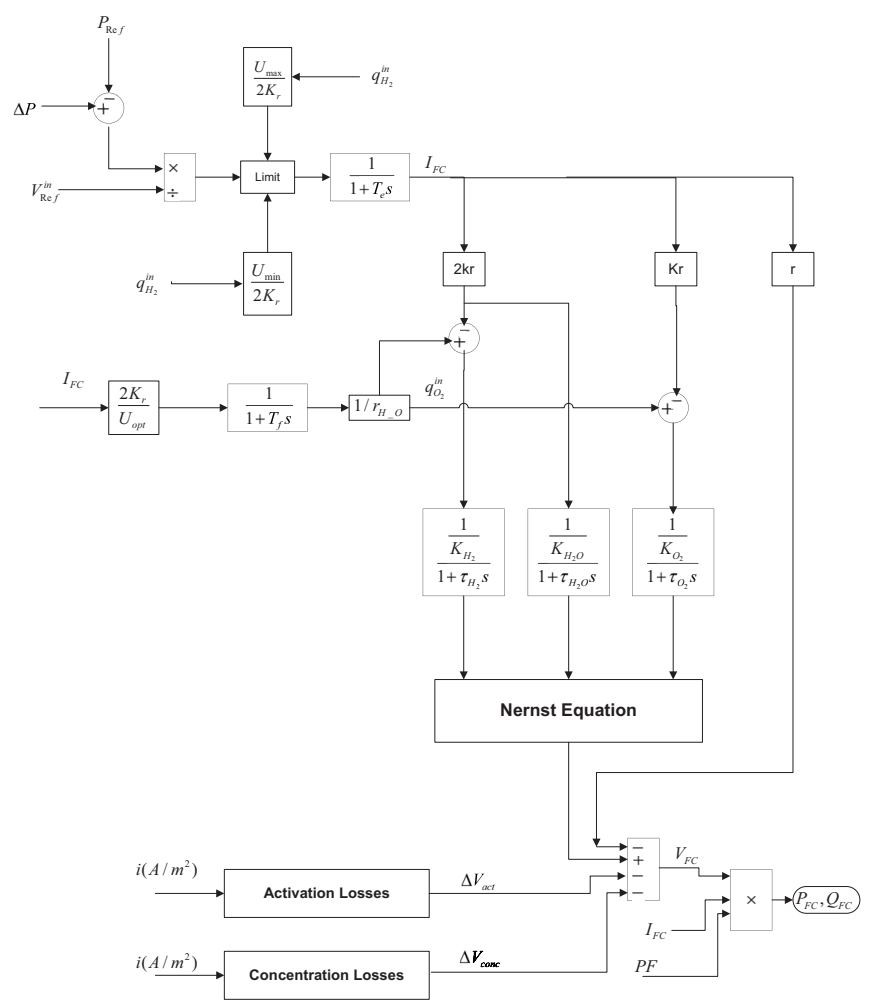

Fig. (1). Simulink model of SOFC.

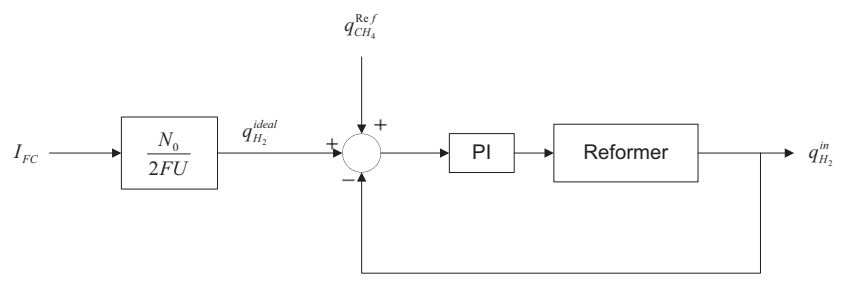

Fig. (2). Methane reformer.

\section{Fuel Processor}

Fuel processor is based in a methane reformer with steam. The transfer function of the reformer model can be expressed as Eq. (11), [8]. Methane reformed is realized with steam $(\mathrm{CV}=3)$.

$$
q_{H_{2}}^{i n}=q_{C_{4}}\left(\frac{C V}{\tau_{1} \tau_{2} s^{2}+\left(\tau_{1}+\tau_{2}\right) s+1}\right)
$$

Reformer output (hydrogen flow) depends of the utilization factor (U) and fuel cell current (IFC). A PI controlled is used to control the flow rate of methane in the reformer, [8]. Fig. (2) presents the block diagram of methane reformer.

$$
q_{\mathrm{CH}_{4}}=\left(\frac{k_{1} \tau_{3} s+k_{1}}{\tau_{3} s}\right)\left(q_{H_{2}}^{\text {ideal }}-q_{H_{2}}^{\text {in }}\right)
$$

\section{Power Conditioning Unit}

Power Conditioning Unit (PCU) consists in a DC/DC converter to raise the output voltage to DC bus voltage and 
$\mathrm{DC} / \mathrm{AC}$ inverter to convert bus voltage to $\mathrm{AC}$. In this paper the DC/DC converter model is omitted. The electrical model of inverter is based on a model developed by El-Sharkh et $a l$., [9]. The inverter inputs are fuel cell voltage $\left(V_{F C}\right)$, modulation index $(m)$ and phase angle on the AC voltage $(\delta)$. The inverter outputs are AC voltage, active and reactive power. In this paper, the load terminal voltage is $400 \mathrm{~V}$ AC for residential and commercial applications.

$$
\begin{aligned}
& V_{A C}=m V_{F C} \angle \delta \\
& P_{A C}=\frac{m V_{F C} V_{L}}{X} \sin (\delta) \\
& \sin (\delta)=\frac{2 F U X}{m V_{L} N_{0}} q_{H_{2}}^{i n}
\end{aligned}
$$

Load terminal voltage is kept constant (400V AC) using a PI controller. PI is used to control modulation index, [9]. Voltage phase angle $(\delta)$ is controlled by the input hydrogen flow $\left(q_{\mathrm{H}_{2}}^{\text {in }}\right)$. Inverter block diagram is showed in Fig. (3).

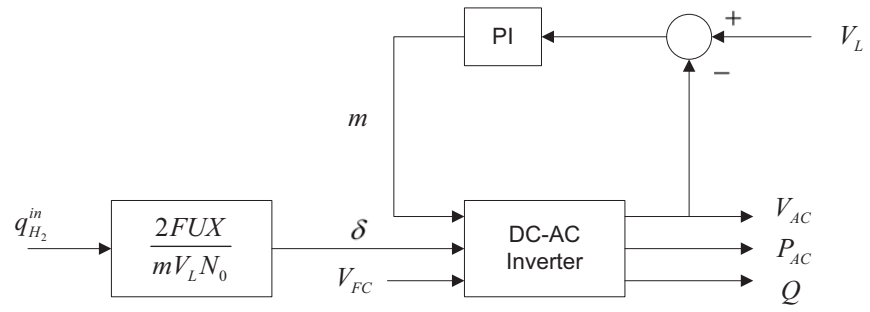

Fig. (3). DC/AC inverter.

$$
m=\frac{k_{2}+k_{3} s}{s}\left(V_{L}-V_{A C}\right)
$$

\section{SIMULATIONS AND RESULTS}

Matlab-Simulink $^{\circledR}$ is used for the modeling and simulation of the fuel processor, fuel cell generator and power conditioning unit, [10]. Figs. (4) and (5) show the voltage and power outputs of the model, respectively. Power demand consists in a step load of $120-140 \mathrm{~kW}$. The initial transients are due to startup of model and the initial conditions of the transfer functions being zero. It can be seen that the fuel cell produces approximately a power step of $120-137 \mathrm{~kW}$ with a $360-420 \mathrm{~A}$ current demand at steady state. The system delivers a voltage of $400 \mathrm{~V}$ AC. The model use a stack consisting 384 fuel cells connected in series, [10].

We can notice, in Figs. (4) and (5), the voltage and power functions don't obtain instantaneously, that is to say, there exists a delay of approximately $20 \mathrm{~s}$. This is due to time responses of SOFC system.

The great inertia of the chemical reactions that takes place in the fuel cell originates the voltage of exit does not become stable even them $350 \mathrm{~s}$ approximately (Fig. 4). The Rolls-Royce Company [11] realizes important advances,

\begin{tabular}{|c|c|}
\hline Parameter & Value \\
\hline Conversion factor, $\mathrm{CV}$ & 3 \\
\hline Load terminal voltage, $\mathrm{V}_{\mathrm{L}}$ & $400 \mathrm{~V}$ \\
\hline Absolute temperature of fuel cell, $T_{F C}$ & $1273 \mathrm{~K}$ \\
\hline Faraday constant, $F$ & $96487000 \mathrm{C} / \mathrm{kmol}$ \\
\hline Universal gas constant, $R$ & $8314 \mathrm{~J} /(\mathrm{kmol} \mathrm{K})$ \\
\hline Standard reversible cell potential, $E_{0}$ & $1.18 \mathrm{~V}$ \\
\hline Number of cells in stack, $N_{0}$ & 384 \\
\hline Proper model constant, $\mathrm{K}_{\mathrm{r}}=\frac{N_{\mathrm{o}}}{4 F}$ & $0.995 \cdot 10^{-6} \mathrm{kmol} /(\mathrm{s} \mathrm{A})$ \\
\hline Maximum use of fuel, $U_{\max }$ & 0.9 \\
\hline Minimal use of fuel, $U_{\min }$ & 0.7 \\
\hline Optimal use of fuel, $U_{\text {opt }}$ & 0.8 \\
\hline Valve's molar constant for hydrogen, $K_{H 2}$ & $8.43 \cdot 10^{-4} \mathrm{kmol} /(\mathrm{s} \mathrm{A})$ \\
\hline Valve's molar constant for water, $K_{H 2 O}$ & $2.81 \cdot 10^{-4} \mathrm{kmol} /(\mathrm{s} \mathrm{A})$ \\
\hline Valve's molar constant for oxygen, $K_{O 2}$ & $2.52 \cdot 10^{-3} \mathrm{kmol} /(\mathrm{s} \mathrm{A})$ \\
\hline Response time for hydrogen flow, $\tau_{H 2}$ & $26.1 \mathrm{~s}$ \\
\hline Response time for water flow, $\tau_{H 2 O}$ & $78.3 \mathrm{~s}$ \\
\hline Response time for oxygen flow, $\tau_{O 2}$ & $2.91 \mathrm{~s}$ \\
\hline Effective ohmic resistance, $r$ & $0.126 \Omega$ \\
\hline Electric response time, $T_{e}$ & $2.5 \mathrm{~s}$ \\
\hline Fuel processor response time, $T_{f}$ & $5 \mathrm{~s}$ \\
\hline Number of electrons exchanged, $n_{e}$ & 2 \\
\hline Rate of exchange for SOFC, $\beta$ & 0,5 \\
\hline Anode current density, $i_{0 a}$ & $6,300 \mathrm{~A} / \mathrm{m}^{2}$ \\
\hline Cathode current density, $i_{0 c}$ & $3,000 \mathrm{~A} / \mathrm{m}^{2}$ \\
\hline Experimental constant, $m_{c}$ & $10^{-4} \mathrm{~V}$ \\
\hline Experimental constant, $n$ & $8 \cdot 10^{-4} \mathrm{~m}^{2} / \mathrm{A}$ \\
\hline Reaction's total area of fuel cell, $A$ & $0,6 \mathrm{~m}^{2}$ \\
\hline Hydrogen-oxygen ratio, $r_{H_{-} O}$ & 1.145 \\
\hline Power factor, $P F$ & 1.0 \\
\hline Lower heating value, $L H V_{C H 4}$ & $800500 \mathrm{~kJ} / \mathrm{kmol}$ \\
\hline Line reactance, $X$ & $0.05 \Omega$ \\
\hline Reformer time constants, $\tau_{1}, \tau_{2}$ & $2 \mathrm{~s}$ \\
\hline PI gain constants for inverter, $\mathrm{k}_{2}, \mathrm{k}_{3}$ & $10 \mathrm{~s}$ \\
\hline Methane reference, $q^{\text {ref }}{ }_{C H}$ & $0.0000005 \mathrm{kmol} / \mathrm{s}$ \\
\hline PI gain constant for reformer, $\mathrm{k}_{1}$ & $0.25 \mathrm{~s}$ \\
\hline
\end{tabular}
managing to create prototypes based on fuel cells and batteries systems to solve this transitory problem.
Table 1. Model Parameters

In Fig. (6), we can see the global efficiency of system generation based on SOFCs. The calculated efficiency corresponds with the Eq. (9) (using LHV of the $\mathrm{CH}_{4}$ ). 


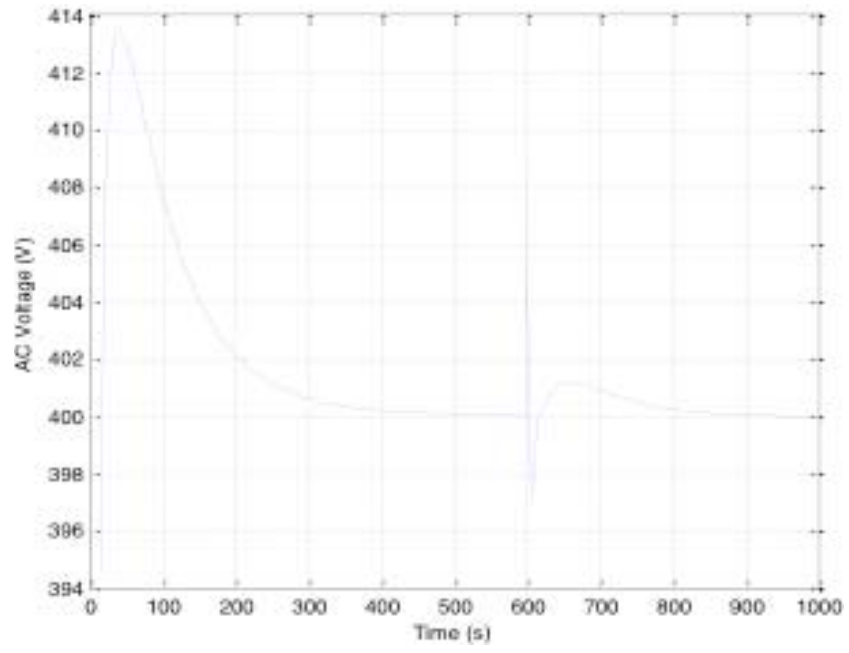

Fig. (4). AC voltage output.

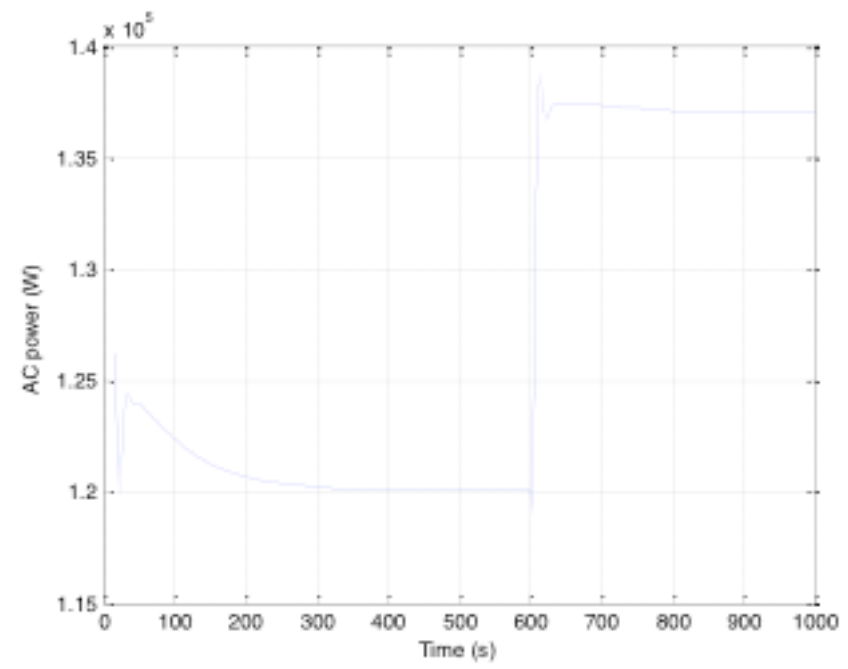

Fig. (5). AC power output.

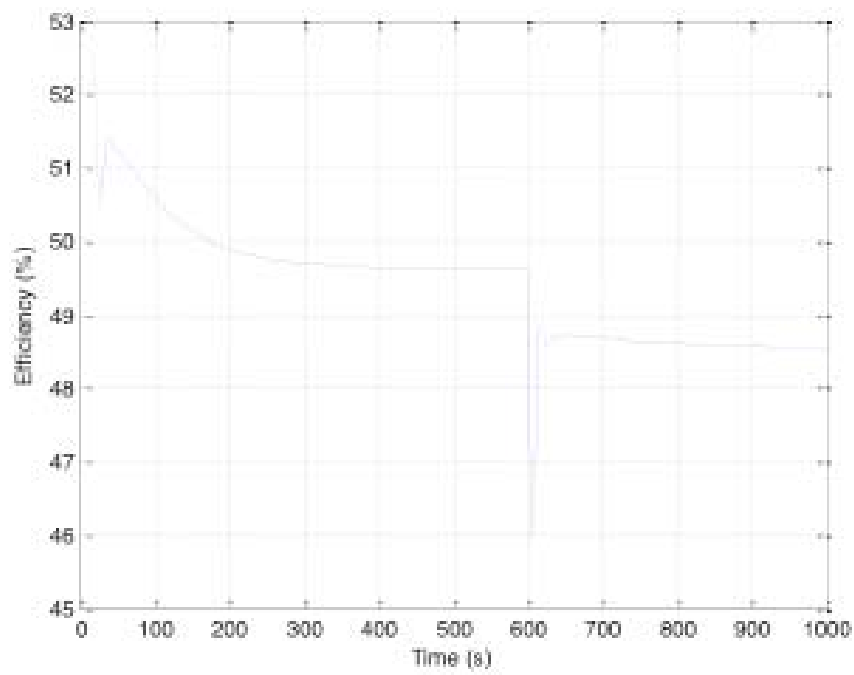

Fig. (6). System generation efficiency.

For a load of $120 \mathrm{~kW}$ (rated power), we can observe the system global efficiency is approximately $50 \%$. This efficiency is greater that obtained one in the conventional power plants by means of other technologies. Besides low $\mathrm{CO}_{2}$ emissions.

Figs. (7, 8 and 9) present reactive output power, AC voltage phase angle $(\delta)$ and fuel flow demanded $\left(q_{\mathrm{CH}_{4}}\right)$. We can observe the reactive power (compared with active power) is practically equal to zero as consequence resistive load (unit power factor).

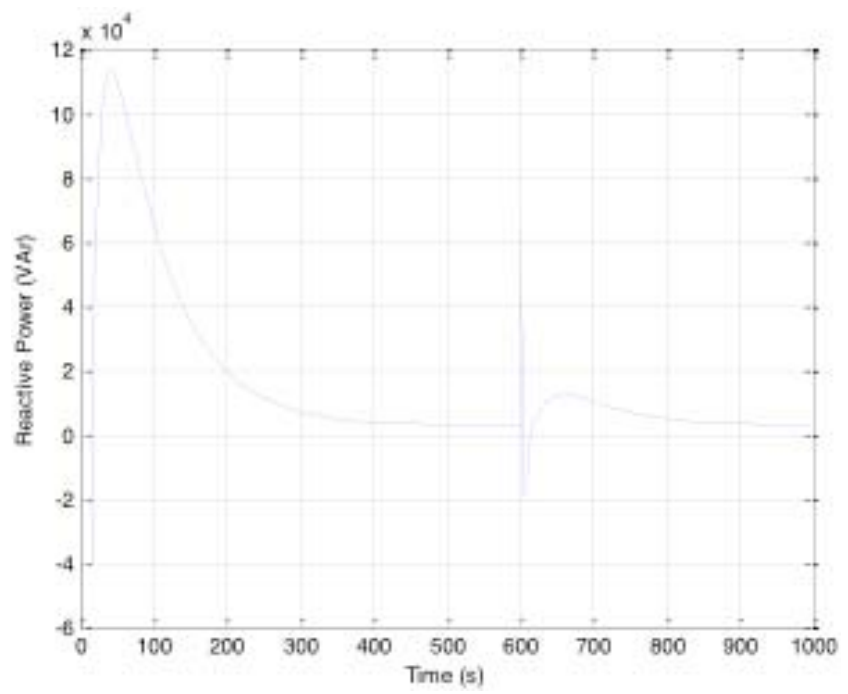

Fig. (7). Reactive power.

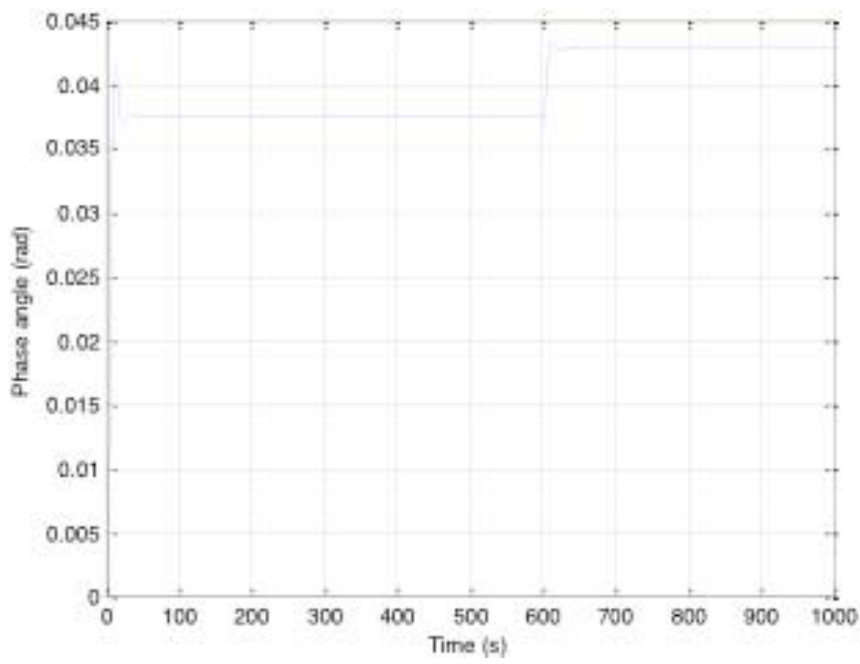

Fig. (8). AC voltage phase angle.

\section{CONCLUSIONS}

In this paper, SOFC based generation system use a stack consisting of 384 fuel cells connected in series, this provides $120-140 \mathrm{~kW}$ output power in stand-alone mode (residential loads). The system has been analyzed when a step load is applied. First, dynamic model of the fuel cell stack is presented, representing properly the slow dynamics associated with the gas flows and the fuel processor operation. Then, a suitable control architecture is presented for the overall system, its objective being to regulate the input fuel flow in order to meet a desirable output power demand, achieving at the same time a near optimal operation of the fuel cells. Mat- 


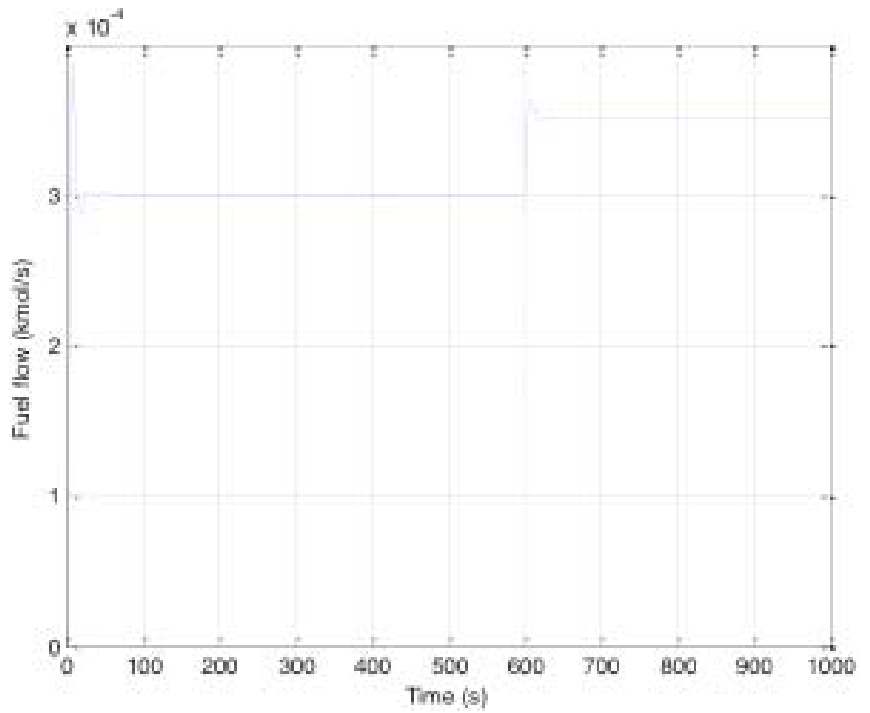

Fig. (9). Fuel flow demanded.

lab-Simulink ${ }^{\circledR}$ is used for the modeling and simulation of the fuel processor, SOFC generator and DC/AC inverter.

\section{NOMENCLATURE}

\begin{tabular}{|c|c|c|}
\hline$C V$ & $=$ & $\begin{array}{l}\text { Conversion factor (kmols of } \mathrm{H}_{2} \text { per } \\
\mathrm{kmols} \text { of } \mathrm{CH}_{4} \text { in reformer reaction) }\end{array}$ \\
\hline$E_{0}$ & $=$ & Standard reversible cell potential (V) \\
\hline$F$ & $=$ & Faraday constant $(\mathrm{C} / \mathrm{kmol})$ \\
\hline$i$ & $=$ & Stack current density $\left(\mathrm{A} / \mathrm{m}^{2}\right)$ \\
\hline$I_{F C}$ & $=$ & Total stack current (A) \\
\hline$i_{0 a}, i_{0 c}$ & $=$ & $\begin{array}{l}\text { Anode and cathode current density } \\
\left(\mathrm{A} / \mathrm{m}^{2}\right)\end{array}$ \\
\hline$L H V_{\text {fuel }}$ & $=$ & Lower heating value of fuel $(\mathrm{kJ} / \mathrm{kg})$ \\
\hline$m$ & $=$ & DC/AC inverter modulation index \\
\hline$m_{c}, n$ & $=$ & $\begin{array}{l}\text { Experimental constant (specific for } \\
\text { SOFC) }\end{array}$ \\
\hline$\dot{m}_{\text {fuel }}$ & $=$ & Fuel flow $(\mathrm{kg} / \mathrm{s})$ \\
\hline$N_{0}$ & $=$ & Number of cells in stack \\
\hline$N_{a}$ & $=$ & Reactant flow to the anode $(\mathrm{kmol} / \mathrm{s})$ \\
\hline$n_{e}$ & $=$ & $\begin{array}{l}\text { Number of electrons exchanged in the } \\
\text { electrochemical reaction }\end{array}$ \\
\hline$P_{A C}$ & $=$ & AC output active power (W) \\
\hline$P_{F C}$ & $=$ & $\begin{array}{l}\text { Electrical power produced by fuel cell } \\
\text { stack (W) }\end{array}$ \\
\hline
\end{tabular}

\begin{tabular}{|c|c|c|}
\hline$p_{i}$ & $=$ & Partial pressure of specie i \\
\hline$r$ & $=$ & $\begin{array}{l}\text { Effective ohmic resistance of SOFC } \\
\text { stack }(\Omega)\end{array}$ \\
\hline$R$ & $=$ & Universal gas constant $(\mathrm{J} / \mathrm{kmol} \mathrm{K})$ \\
\hline$s$ & $=$ & Laplace transform \\
\hline$T_{F C}$ & $=$ & Temperature ok fuel cell stack $(\mathrm{K})$ \\
\hline$U$ & $=$ & Average fuel utilization \\
\hline$V_{A C}$ & $=$ & AC output voltage (V) \\
\hline$V_{0}$ & $=$ & Reversible cell voltage \\
\hline$V_{F C}$ & $=$ & Cell voltage (V) \\
\hline $\mathrm{V}_{\mathrm{L}}$ & $=$ & Load terminal voltage (V) \\
\hline$X$ & $=$ & Line reactance $(\Omega)$ \\
\hline$y_{i}$ & $=$ & $\begin{array}{l}\text { Mole fraction of fuel species } i \text { in the } \\
\text { anode gas }\end{array}$ \\
\hline$\delta$ & $=$ & AC voltage phase angle (rad) \\
\hline$\Delta G_{0}$ & $=$ & Change in Gibbs free energy (V) \\
\hline$\Delta \mathrm{V}_{\text {act }}$ & $=$ & Activation losses (V) \\
\hline$\Delta V_{\text {conc }}$ & $=$ & Concentration losses (V) \\
\hline$\Delta V_{\text {ohm }}$ & $=$ & Ohmic polarization losses (V) \\
\hline$\eta_{F C}$ & $=$ & Fuel cell efficiency \\
\hline
\end{tabular}

\section{REFERENCES}

[1] Larminie, J.; Dicks, A. Fuel Cell Systems Explained, s.l., John Wiley \& Sons, 2000.

[2] Blomen, L.; Mugerwa, M. Fuel Cell Systems. s.l., Plenum Press, 1993.

[3] Jurado, F.; Valverde, M.; Cano, A. Effect of a SOFC plant on distribution system stability. J. Power Sources, 2004, 129, 170-179.

[4] Padullés, J.; Ault, G.W.; McDonald, J.R. An integrated SOFC plant dynamic model for power systems simulation. J. Power Sources, 2000, 86, 495-500.

[5] Chan, S.H.; Khor, K.A.; Xia, Z.T. A complete polarization model of a solid oxide fuel cell and its sensitivity to the change of cell component thickness. J. Power Sources, 2001, 93, 130-140.

[6] Hahn, A. Thesis, University of Pittsburgh, 2000.

[7] The Math Works. MATLAB ${ }^{\circledast}$ and SIMULINK ${ }^{\circledast}$ Software. Version 7.1.2005.

[8] El-Sharkh M.Y.; Sisworahardjo, N.S.; Uzunoglu, M.; Onar, O.; Alam, M.S. Dynamic behavior of PEM fuel cell and microturbine power plants. J. Power Sources, 2007, 164, 315-321.

[9] El-Sharkh, M.Y.; Rahman. A.; Alam, M.S.; Sakla, A.A.; Byrne, P.C.; Thomas, T. Analysis active and reactive power control of a stand-alone pem fuel cell power plant. IEEE Trans. Power Syst., 2004, 19(4), 2022-2028.

[10] Vera, D. Master Thesis, University of Jaén, 2007.

[11] Rolls-Royce Company. http://www.rolls-royce.com/energy/tech/ fuelcells.jsp

(C) Vera and Jurado; Licensee Bentham Open.

This is an open access article licensed under the terms of the Creative Commons Attribution Non-Commercial License (http://creativecommons.org/licenses/by-nc/3.0/) which permits unrestricted, non-commercial use, distribution and reproduction in any medium, provided the work is properly cited. 